\title{
EXTENDING THE THEORY OF PLANNED BEHAVIOR WITH RELIGIOSITY: EXPLAINING ENTREPRENEURIAL INTENTION OF EMPLOYEES STUDENTS
}

\author{
Hermansyah Andi Wibowo*)1, Hamdan*), Muhammad Kamil Husain*) \\ ${ }^{*}$ Department of Management, Faculty of Economics and Business, Universitas Serang Raya \\ Jl. Raya Cilegon Km. 5, Kota Serang, Banten 42162 Indonesia
}

\begin{abstract}
Employees students face major threats related to the development and implementation of the industrial revolution 4.0. However, how employees students handle this situation scientifically is rarely found in the behavioural science literature. This study tries to fill this gap and at the same time extends the Theory of Planned Behavior by adding a variable of religiosity. A total of 421 Muslim students in Banten Province who are still working, were sampled using the purposive sampling method. Structural Equation Modeling is used to test hypotheses simultaneously. The results showed that all independent variables, namely religiosity, subjective norms, and perceived behavioural control had a positive effect on the entrepreneurial intentions of employees students. That is, although the influence of religiosity is second only to perceived behavioural control, empirically, extending the theory of planned behaviour with religiosity is still acceptable. For policymakers, the results of this study can be used to make policies that can increase perceptions about the ease of doing business in Indonesia, especially for employees students.
\end{abstract}

Keywords: employees students, the theory of planned behaviour, religiosity, industry 4.0 , entrepreneurial policy

\begin{abstract}
Abstrak: Mahasiswa karyawan menghadapi ancaman besar terkait dengan perkembangan dan implementasi revolusi industri 4.0. Akan tetapi, bagaimana mahasiswa karyawan menangani situasi ini secara ilmiah jarang ditemukan dalam literatur ilmu keperilakuan. Penelitian ini mencoba mengisi celah tersebut sekaligus memperluas Theory of Planned Behavior dengan menambahkan variabel religiusitas. Sebanyak 421 mahasiswa muslim di Provinsi Banten yang masih bekerja, dijadikan sampel dengan metode purposive sampling. Structural Equation Modeling digunakan untuk menguji hipotesis secara bersamaan. Hasil penelitian menunjukkan bahwa semua variabel bebas yaitu religiusitas, norma subjektif, dan kendali perilaku persepsian berpengaruh positif terhadap niat berwirausaha mahasiswa karyawan. Artinya, meskipun pengaruh religiusitas adalah yang kedua setelah kendali perilaku persepsian, secara empiris, memperluas teori perilaku terencana dengan religiusitas masih dapat diterima. Bagi pengambil kebijakan, hasil penelitian ini dapat digunakan untuk membuat kebijakan yang dapat meningkatkan persepsi tentang kemudahan berusaha di Indonesia khususnya bagi mahasiswa karyawan.
\end{abstract}

Kata kunci: mahasiswa karyawan, teori perilaku terencana, religiusitas, industri 4.0, kebijakan kewirausahaan

\footnotetext{
${ }^{1}$ Corresponding author:

Email: hermansyahandiwibowo@gmail.com
} 


\section{INTRODUCTION}

In society, the implementation of Industrial Revolution 4.0 (IR 4.0) can have a negative impact on the careers of blue-collar workers. Why is that? Because the work that is usually done by these workers is very possible to be replaced by intellectual activity, namely automation of processes and production by intelligent machines (Bogoviz et al. 2019). Indeed, there will be a new profession from the IR 4.0, but the skills and knowledge required, with inherent limitations, such as time, are difficult for blue-collar workers to master (Wibowo and Indarti, 2020), even if they are highly educated students. In this situation, blue-collar workers should decide either to upgrade relevant competencies or to start a business while working. The first option is a tough choice, because of the rapid advancement of technology that is rapidly destroying several competencies. In addition, the emergence of new job seekers will increase the temperature of competition in finding and keeping jobs. A wiser choice is to try entrepreneurship while still working. How their entrepreneurial intentions are formed is important to know by policymakers?.

Regarding human behaviour prediction, the Theory of Planned Behavior or TPB (Ajzen, 1991) which consists of three independent variables, viz. attitude, subjective norms (SN), perceived behavioural control (PCB) and 2 dependent variables, viz. behavioural intention and actual behaviour, has been widely used by researchers to predict human behaviour. TPB with an emphasis on the role of subjective norms predicted purchase intention of organic food (Huque et al. 2014); TPB with an emphasis on forming attitudes that are influenced by consumer value, has also successfully demonstrated its robustness in predicting online food buying behaviour (Hansen, 2008); Longitudinal studies which applied TPB, with an emphasis on shaping perceptions of behavioural control, have found support to be extended by trust and technology adoption variables (Pavlou and Fygenson, 2006); ТPB is compared with the Technology Acceptance Model (TAM) and both have good predictive abilities (Fusilier and Durlabhji, 2005); TPB in the field of entrepreneurship has grown rapidly in 20 years (Lortie and Castogiovanni, 2015).

Historically, TPB was the Theory of Reasoned Action (TRA) which was extended with the PCB variable. Lortie and Castogiovanni (2015) confirm this by stating that "PCB is an integral factor that separates TPB from
TRA". Both theories assume that humans behave using rational considerations. In the scientific literature, Wibowo and Indarti (2020) have obtained empirical evidence about the effectiveness of extending TRA with religiosity variables in the context of blue-collar workers. Wibowo (2017) also obtained similar empirical support in the context of the intention of hijab-wearing in Indonesia. The expansion of the TPB with perceived value (PV) and willingness to pay a premium (WPP) in the context of green product purchases, has provided empirical support for PV but not for WPP (Yadav and Pathak, 2017). In the present work, the same extension with religiosity will be applied to the TPB in the context of employees students entrepreneurial intentions. Therefore this research is a continuation of what has been done by Wibowo and Indarti (2020).

In addition to contextualization in its use to explain phenomena, ideas for developing TPB form are also increasing. In the context of religious people, we believe that the assumption of rationality can be carried out together with the aspect of religiosity when a research sample is a group of people who have religiosity. Ajzen (2020) stated "..additional independent variables should be carefully proposed and included in the TPB, and only after careful consideration and empirical exploration. From the initial observations, we found the characteristics of the sample from Bantenese that support the idea of adding religiosity to TPB. Wibowo and Indarti (2020) argued that when Islamic values such as being independent, helping the poor, and perfecting work are adequately socialized to someone, those values will become the basis of someone to behave. These values will determine the formation of salient belief which is the basis of one's attitude in dealing with certain situations.

With an empirical phenomenon-secret interviewed of 20 respondents- namely the problems faced by employees students related to the threat of IR 4.0 implementation, where the logical solution is to start a business. Added to this is the scientific issue of using the extended TPB with religiosity to predict the rational behaviour of a religious sample, we combine this empirical phenomenon with scientific issues. We then extracted the research problem and set the research objectives as follows: 1) Is the extension of the TPB with religiosity empirically supported? 2) Is the TPB model extended with religiosity able to explain well the formation of entrepreneurial intentions? Thus, the purpose of this study is to first conduct an empirical test whose 
results are expected to support the notion of extending TPB with religiosity. This purpose is achieved if all hypotheses are empirically supported. The second, to explain the phenomenon of the formation of employees students entrepreneurial intentions using the extended model of TPB. Third, the comparison of the magnitude of the influence of each independent variable on the dependent variable will also be studied. Furthermore, we focus on discussing the issue of model extension instead of discussing the effects of independent variables one by one.

\section{METHODS}

The research subjects were working students from all cities and districts in Banten Province. Purposive sampling was executed with the criteria of the research sample, namely: students as well as factory employees, evidenced as Muslims by ID cards or based on their recognition. Of the 550 questionnaires distributed, there were 474 copies filled out from 537 ones received. This number is reduced again because there were respondents whose answers were infected with a multivariate outlier -the probability of Mahalanobis Distance is less than 0.001 (Grande, 2015). The final number used in the study was 421 respondents.

Data collection was carried out through observation, interviews, documentation, and a literature study with the main instrument of the questionnaire. Observations on several respondents were carried out physically. Unstructured interviews with 20 respondents were conducted in a classroom and the process was kept secret from the respondents.

Measurement of variables of religiosity, attitudes towards entrepreneurship, and SN were measured by the research instrument used by Wibowo and Indarti (2020). Meanwhile, behaviour control variables were developed by referring to Ajzen, (2010). The Latent Variable Score (LVS) was used to simplify the construct of religiosity. This technique is proven not to eliminate the characteristics captured by the indicator as dimensional elements (Wibowo and Indarti, 2020). The development of a scale of attitudes towards entrepreneurial behaviour and who are important social actors for respondents was carried out by paying attention to the results of the interviews of 20 respondents at the beginning of data collection. The indicator is quantified by a Likert score of 1 to 5 where $1=$ strongly disagree, $2=$ disagree, $3=$ doubt, $4=$ agree, $5=$ strongly agree.

Before being tested with structural equation modelling (SEM), the dimensionality of the data was confirmed by factor analysis. Furthermore, convergent validity is tested using confirmatory factor analysis (CFA) where the latent variable has sufficient convergence if the minimum Standardized Loading Factor (SLF) value for each item or indicator is 0.5 , ideally 0.7 or higher (Hair et al. 2014). Discriminant validity is obtained when the correlation between the squared constructs is smaller than the Average Variance Extracted (AVE) of the construct.

Reliability is tested with a cut off Composite Reliability (CR) value greater than 0.70 and AVE with a cut off value of 0.5 (Hair et al. 2014). The results of the structural model Goodness of Fit (GoF) test use the criteria for the value of RMSEA $<0.08$, NFI, NNFI, CFI, IFI, RFI, and GFI, respectively, which are above 0.9 . The absence of agreement on the absolute GoF criteria from SEM (Wijanto, 2008) underlies the selection of the $7 \mathrm{GoF}$ criteria in this study. The acceptance/ rejection of the research hypothesis is determined by the significance of the path coefficients in the structural model. The path is significant if the t-statistic value is $>$ 1.96 at the significance level $\alpha=5 \%$. Determination of the direction of the relationship is based on the $+/$ - sign of the path coefficient.

This study defines religiosity as a person's conformance with his/her religious teachings, which is a reflection of basic beliefs, understanding of the main task, spiritual experience, knowledge, and orthopraxy in religion. This definition follows El-Menouar (2014), Meanwhile, attitude is an evaluative tendency based on one's belief in the results obtained, and it leads someone to tend to a certain direction in the form of assessment, agreedisagree, or positive-negative. It is an evaluation of a person, whether positive or negative and their beliefs or feelings (Fishbein and Ajzen, 1975). Attitudes towards entrepreneurial results are what is executed in this study. $\mathrm{SN}$ are perceptions about other people's opinions on an object (Wibowo and Indarti, 2020). Therefore, the social actors who are important to the subject, need to be clearly defined. 
The definition of intention to behave follows Ajzen (1991) who states that intention to behave shows "how hard people want to try" and "how much effort they plan to do" (Ajzen, 1991). The object of intention to behave in this study is the intention to start a business while still working. As the result of adequate socialization (see Mala et al. (2020)), the values taught in Islam such as the importance of giving the inheritance to the offspring, assisting the poor (Al-Bukhari No. 590, no date); and the belief in Allah's view and closeness when serving Him, paying zakat and performing Hajj (Nawawi No. 2 , no date); etc., will become a basis for a person to behave in certain ways (Wibowo and Indarti, 2020). Empirically, in a consistent manner of hijab-wearing, religiosity affects attitudes and intentions to behave, while at the same time eliminating the relationship between attitude and intention to behave (Wibowo and Masitoh, 2018). Therefore, the hypothesis proposed is:

H1. Religiosity has a positive effect on entrepreneurial attitudes.

H2. Religiosity has a positive effect on entrepreneurial intentions.

In the context of generation $\mathrm{Y}$, the influence of attitudes on purchase intention (Khalek and Ismail, 2015) takes a sharia mortgage (Alam et al. 2012) and stays at a sharia hotel (Shakona, 2013). Attitudes influence the intention to become a customer of a sharia bank (Souiden and Rani, 2015). Attitudes towards piracy also have a positive effect on the intention to pirate digital content (Yoon, 2011). Personal attitude influences and strengthens intentions among students as nascent entrepreneurs (Wibowo, 2019).

SN are perceptions about other people's opinions on an object (Wibowo and Indarti, 2020). Therefore, the social actors who are important to the subject, need to be clearly defined. Our initial data collection revealed that parents, husband/wife, boy/girlfriend, lecturer, co-workers, were important social actors for the respondents. Empirically, SN has a positive effect on entrepreneurial intentions (Wibowo and Indarti, 2020); $\mathrm{SN}$ also have a positive effect on purchase intentions of organic food (Huque et al. 2014). Behavioural control refers to the perceived ease or difficulty in performing the behaviour and is thought to reflect past experiences as well as anticipated obstacles (Ajzen, 1991). Behavioural control has a positive effect on intentions to shop for food online (Hansen, 2008). Behaviour control has a positive effect on both intention and online buying behaviour (Pavlou and Fygenson, 2006). PCB influences the formation and strengthens intentions among students as nascent entrepreneurs (Wibowo, 2019). With the empirical findings that support the proposition in the TPB, the proposed hypothesis is as follows:

H3. Attitudes have a positive effect on entrepreneurial intentions.

H4. Subjective norms have a positive effect on entrepreneurial intentions

H5. Perceived behaviour control has a positive effect on entrepreneurial intentions.

We provide Figure 1 and Figure 2 to provide an overview through the comparison and transformation of the TPB model carried out in this study. Although there is a scientific debate about the representation of behaviour by behavioural intentions and how long the tolerable delay is for behavioural intentions to become actual behaviour, the development of behavioural science is largely contributed by researchers using intention models. It appears that pragmatism in the scientific world contributes more to the development of behavioural science. Practically using the complete TPB model with actual intention and behaviour being the dependent variable, it is very rare to find. Lortie and Castogiovanni (2015) only found one article that conducted empirical research on TPB with a complete model. Therefore, we are following the mainstream of TPB utilization and modifying it to suit our research context.

\section{RESULTS}

\section{Descriptive Statistic}

Respondents of this study were 208 men and 213 women. The youngest respondent was 18 years old while the oldest was 52 years old, the mode age was 22 and the mean was 26.5 years old. More than $80 \%$ of respondents live in Cilegon City, Serang Regency, Serang City, and Tangerang Regency. The rest live in other districts and cities in Banten Province. 74.8\% percent of respondents provide income data, that the lowest respondent's income was IDR 800,000 and the highest was IDR27,000,000. The average income was IDR3,217,829 with a standard deviation of IDR2,126,621. 


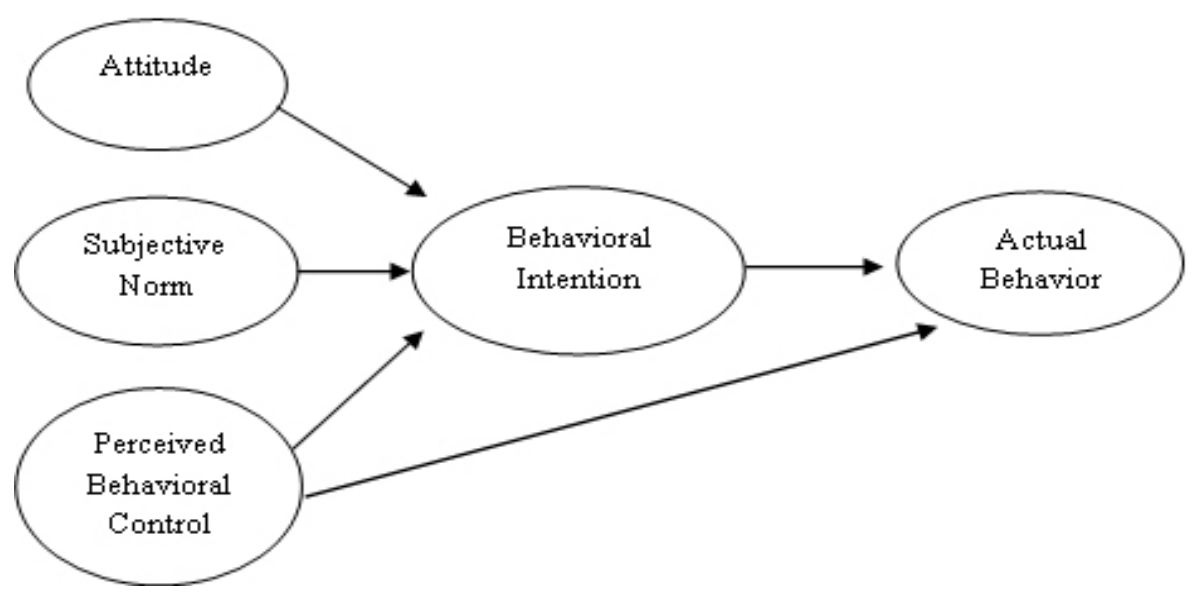

Figure 1. The theory of planned behavior (Ajzen, 1991)

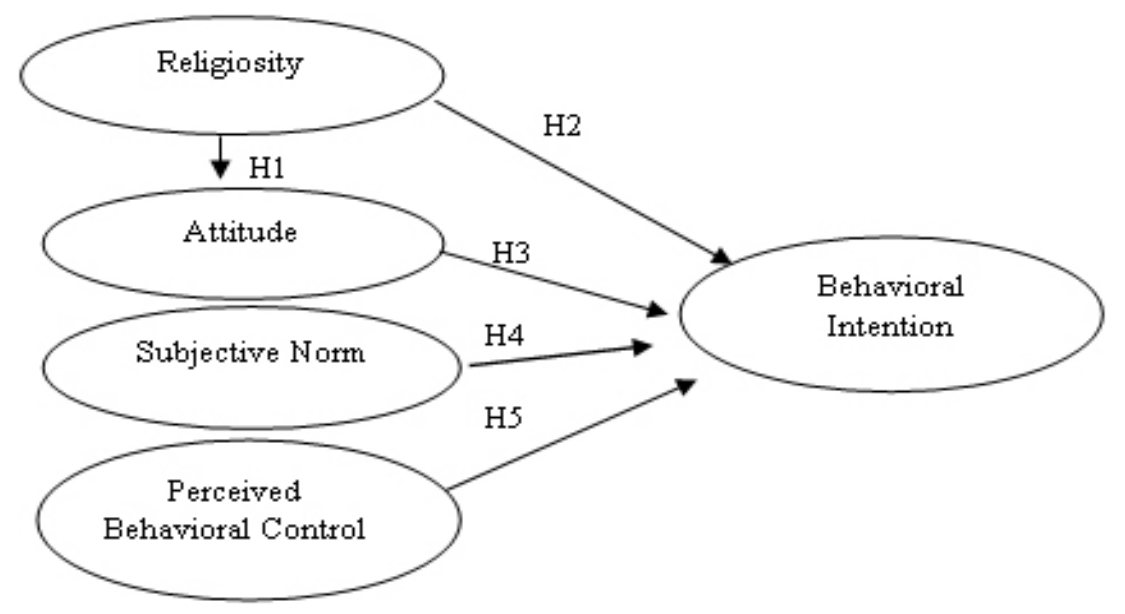

Figure 2. The proposed model (Ajzen, 1991)

In general, it can be said that the respondents were in the pre-adult phase based on age inclination (mean $<$ mode). It can also be stated that the majority of respondents are generation Y (Gen Y) who were born between 1981 to 1996 (www.wikipedia.org, 2019). Gen Y is generally identified by elevated usage of the internet, social media, and mobile devices. We assume they are aware of the issue of IR 4.0. and this assumption has been confirmed in the initial data collection. The gender composition was almost the same (no sex bias in the study). The high standard deviation of the respondent's income indicates a high variation in the respondent's income.

\section{Validity dan Reliability}

Following are tables $1 \mathrm{a}$ and $1 \mathrm{~b}$, which display the results of the construct validity and reliability tests. Table $1 \mathrm{a}$. shows that all indicators of research variables have good convergent validity because they have SLF above
0.5. This means that the indicators in this study are confirmed to be grouped on variables according to the theory used. The indicators on the same latent variable have a high correlation with each other. Construct reliability is also qualified because all constructions have CR above 0.7 and AVE above 0.5.

Table $1 \mathrm{~b}$ shows that all constructs have good discriminant validity because the correlation value of the variable referred to with other variables is smaller than the AVE square value of the variable in question. This means that the indicators of this study do not reflect latent variables that are not following the theory used.

\section{Goodness of Fit}

In Table 2, all the criteria required and selected as indicators of the feasibility of the model are met by this research model. 
Table 1a. Convergencies and reliability

\begin{tabular}{|c|c|c|c|c|c|}
\hline Variables & Items & SLF & errors & $\mathrm{CR}$ & AVE \\
\hline \multirow[t]{3}{*}{ Attitude } & $\mathrm{S} 1$ & 0.77 & 0.41 & 0.79 & 0.56 \\
\hline & $\mathrm{S} 2$ & 0.76 & 0.42 & & \\
\hline & S5 & 0.71 & 0.49 & & \\
\hline \multirow[t]{4}{*}{ Subjective Norm } & $\mathrm{N} 2$ & 0.78 & 0.39 & 0.85 & 0.58 \\
\hline & N3 & 0.8 & 0.36 & & \\
\hline & N4 & 0.78 & 0.4 & & \\
\hline & N5 & 0.69 & 0.52 & & \\
\hline \multirow[t]{5}{*}{ Perceived Behavioral Control } & $\mathrm{k} 1$ & 0.72 & 0.49 & 0.87 & 0.63 \\
\hline & $\mathrm{k} 2$ & 0.8 & 0.37 & & \\
\hline & $\mathrm{k} 3$ & 0.86 & 0.25 & & \\
\hline & $\mathrm{k} 4$ & 0.8 & 0.36 & & \\
\hline & I1 & 0.9 & 0.19 & & \\
\hline \multirow[t]{2}{*}{ Entrepreneurial intention } & I3 & 0.84 & 0.29 & 0.90 & 0.74 \\
\hline & I4 & 0.84 & 0.29 & & \\
\hline \multirow[t]{2}{*}{ Religiosity } & Task & 1 & 0 & 0.82 & 0.71 \\
\hline & Orto & 0.65 & 0.58 & & \\
\hline
\end{tabular}

Tabel 1b. Discriminant Validity

\begin{tabular}{lccccc}
\hline \multicolumn{1}{c}{ Squared AVE } & Attitude & $\begin{array}{c}\text { Entrepreneurial } \\
\text { Intention }\end{array}$ & Religiosity & $\begin{array}{c}\text { Subjective } \\
\text { Norm }\end{array}$ & $\begin{array}{c}\text { Behavioral } \\
\text { Control }\end{array}$ \\
\hline Attitude & 0.75 & 0.18 & 0.23 & 0.03 & 0.05 \\
Entrepreneurial Intention & 0.18 & 0.86 & 0.30 & 0.52 & 0.76 \\
Religiosity & 0.23 & 0.30 & 0.84 & 0.12 & 0.22 \\
Subjective Norm & 0.03 & 0.52 & 0.12 & 0.76 & 0.58 \\
Behavioral Control & 0.05 & 0.76 & 0,22 & 0.58 & 0.80 \\
\hline
\end{tabular}

Tabel 2. Model Fit

\begin{tabular}{lccc}
\hline \multicolumn{1}{c}{ Criteria } & Cut Off & Estimates & Decisions \\
\hline RMSEA & $<0.08$ & 0.075 & Good Fit \\
NFI & $>0.9$ & 0.95 & Good Fit \\
NNFI & $>0.9$ & 0.96 & Good Fit \\
CFI & $>0.9$ & 0.97 & Good Fit \\
\hline
\end{tabular}

\section{Hypothesis Testing}

In Table 3, we can see that all the research hypotheses were accepted. This is because the $t$ statistical value of all paths is in the significant category (values above 1.96 at $\alpha=5 \%$ ). It also clear/ also clearly explains that the direct effect of behavioural control on entrepreneurial intentions is the greatest influence exerted by an independent variable in this model. Religiosity is on the second rank, though if calculated by calculating the total effect, which is 0.14 . This result was obtained from the direct influence on the intention to behave at 0.12 plus the indirect effect through attitude, namely $0.23 \times 0.11$.

\begin{tabular}{lccl}
\hline \multicolumn{1}{c}{ Criteria } & Cut Off & Estimates & Decisions \\
\hline IFI & $>0.9$ & 0.97 & Good Fit \\
RFI & $>0.9$ & 0.94 & Good Fit \\
GFI & $>0.9$ & 0.91 & Good Fit \\
\hline
\end{tabular}

This study provides support for the notion of extending the TRA model (Wibowo, 2017) (Wibowo and Indarti, 2020) and the TPB model with the addition of the religiosity variable. Empirical support in other contexts is still needed to strengthen the relationship pattern between religiosity and attitudes. In the context of employees students, both described by TRAandTPB, the result is the same, namely, religiosity is an antecedent of one's attitude towards an object as well as the predictor of one's intention. This makes sense considering the teachings of Islam provide knowledge - particularly aqidah - as a guide for one's life. Islamic values that are repeatedly tested through a person's experience, will become his/her beliefs regarding certain objects. 
In this study, attitudes towards entrepreneurship and entrepreneurial intentions are influenced by a person's level of religiosity.

The results of this study provide support for all the hypotheses proposed here. The support of H1, H2, $\mathrm{H} 3$, and $\mathrm{H} 4$ strengthens the findings in previous work (Wibowo and Indarti, 2020). Meanwhile, Wibowo and Masitoh (2018) who specifically examined the relationship pattern between religiosity, attitude, and behavioural intention (Wibowo and Masitoh, 2018), received support from the evidence of $\mathrm{H} 1$ and $\mathrm{H} 2$ in this study. However, their research failed to find evidence that showed a relationship between attitude and behaviour intention. Particularly for Wibowo and Masitoh's findings for which we hold the data when the respondent gives a superior assessment to her religiosity, the classic problem in mental models, viz. social desirability bias, was very severe to happen. A high level of religiosity will eliminate the relationship between a person's attitude and behaviour. This means, high religiosity affects a person's attitudes and behaviour directly and a person does not have to have a certain attitude to further behave. In future research, we will provide proof of this social desirability bias using the Rasch model.

The empirical findings of this study support the effect of $\mathrm{SN}$ on entrepreneurial intentions (H4). The $\mathrm{H} 4$ findings also corroborate the findings of Huque et al. (2014). In our study, SN that also affect employees students' entrepreneurial intentions consists of respondents' assessments of the perceptions of important social actors in their lives. Here the social actors are husband/wife, boy/girlfriends, lecturers, and coworkers. Assessment/ pressure from parents is not an important consideration for respondents to start a business. It was eliminated from the model.
This study also provides empirical support that behavioural control has a positive effect on entrepreneurial intentions (H5), as found by Hansen (2008) in the context of shopping at online food stores, and online shopping in general (Pavlou and Fygenson, 2006). PCB also influences the formation and strengthens intentions among students as nascent entrepreneurs. (Wibowo, 2019). As the variable in our study which has the greatest influence on variations in entrepreneurial intentions, PCB contains respondents' assessments of themselves regarding capital, network relationships, talents, and skills that they will use in starting a business. PCB indicated the rationality of the respondents is higher than religiosity and social pressure. The rationality here is seen from the respondent's selfefficacy which consists of their assessment of capital ownership, network relationships, talents, and skills, which are needed to start a business.

Comparing the weight of the influence of the independent variables on the dependent variable, in the context of employees students, it turns out that behavioural control has the greatest influence on variations of entrepreneurial intentions. This means that employees students who have to deal with and anticipate the negative impacts of implementing IR 4.0 act rationally with the main consideration of the perception of ease and ability to carry out entrepreneurial behaviour. Starting a business is a choice that requires rational consideration. Although religious beliefs and religious recommendations for entrepreneurship are very high, the final decision still considers the ability to carry out, which is subjectively reflected by PCB. This result does not change our belief that the extension of TPB with religiosity is valid and convincing.

Tabel 3. Hypothesis testing results

\begin{tabular}{|c|c|c|c|c|}
\hline Hypothesis & Paths & Standardized Value & $\mathrm{T}$ Value & Decision \\
\hline $\mathrm{H} 1$ & Religiosity $\rightarrow$ Attitude & 0.23 & 4.30 & Accepted \\
\hline $\mathrm{H} 2$ & Religiosity $\rightarrow$ Entrepreneurial Intention & 0.12 & 3.02 & Accepted \\
\hline H3 & Attitude $\rightarrow$ Entrepreneurial Intention & 0.11 & 2.62 & Accepted \\
\hline H4 & Subjective Norm $\rightarrow$ Entrepreneurial Intention & 0.13 & 2.47 & Accepted \\
\hline H5 & Perceived Behavioral Control $\rightarrow$ Entrepreneurial Intention & 0.66 & 11.52 & Accepted \\
\hline
\end{tabular}


With the discussion that has been described, we are confident in stating that the model we have proposed and has been tested is worthy of being used to explain or to predict employees students entrepreneurial intentions. To obtain intersubjective verification-verifiable (HUNT, 1991), testing this model can be carried out in other contexts as long as the behaviour being explained is rational and the sample members have religiosity. Specifically, we give an example of predictions related to behaviour related to religious orders, e.g. doing Hajj, paying zakat, donations, eid homecoming trip, Islamic banking etc.)

In this study, the PCB of the respondents was measured by considering the financial capital, network, talents, and skills of the respondents. Therefore, the results of this study can be used as a basis for local governments -which must be rational in solving problems- to make policies that are oriented towards the ease of creating new businesses. This policy is in the form of facilitating the ease of licensing for the creation of new businesses; providing training that improves entrepreneurship skills; increasing the ease of access to bank credit; and relationship-oriented policies, such as providing easy physical exhibitions and an online marketplace that is SME-friendly.

\section{Managerial Implications}

In this study, the PBC of the respondents was measured by considering the financial capital, network, talents, and skills of the respondents. Therefore, the results of this study can be used as a basis for local governments which must be rational in solving problems to make policies that are oriented towards the ease of creating new businesses. This policy is in the form of facilitating the ease of licensing for the creation of new enterprises; provide trainings that improve entrepreneurship skills; increasing the ease of access to bank credit; and relationship-oriented policies, such as providing accessible physical exhibitions and an online marketplace that is Small and Medium Enterprisefriendly.

\section{CONCLUSIONS AND RECOMMENDATIONS}

\section{Conclusions}

This study provides strong empirical support that the extension of TPB with religiosity is acceptable. This is because all the hypotheses proposed are supported empirically. Our model was valid in representing respondents' mental phenomena and we encourage other researchers to re-examine it in different contexts. We also acknowledge that the determinant with the greatest influence on the variation of entrepreneurial intention is $\mathrm{PCB}$, the second rank is religiosity and the third is the subjective norm. In other words, student employees behave very rationally from the point of view that they consider themselves capable or not. Although religion gives beliefs and advice to employees students for entrepreneurship as well as important social actors also put pressure on their behaviour, students'entrepreneurial intentions are most influenced by the perception that they are able or not to carry it out. Specifically, this study shows that variations in student entrepreneurship intentions are more influenced by perceived comfort in the form of capital support and relationships as well as self-efficacy which is represented as an indicator of the $\mathrm{PCB}$ variable.

\section{Recommendations}

We recommendations other researchers who are interested in the topic of model extension, retest our model which proved to be very good in entrepreneurial intentions. Verification between researchers is very much needed to contribute to the development of science as well as practice that is effective and efficient.. In practice or for the benefit of policymakers, the results of this study provide direction in the form of the importance of making policies that increase perceptions of ease or support for creating new businesses. Examples are ease of licensing, easy access to banking credit, facilitation of exhibitions, and training to improve skills.

\section{ACKNOWLEDGMENT}

The author would like to thank donors of this research, viz. the Ministry of Research, Technology and Higher Education and the National Research \& Innovation Agency.

\section{REFERENCES}

Ajzen I. 1991. The theory of planned behavior. Organizational Behavior and Human Decision Processes 50(2):179-211.

Ajzen I. 2010. Constructing a theory of planned behavior 
questionnaire. Biofeedback and Selfregulation 17:1-7. https://people.umass.edu/aizen/pdf/tpb. measurement.pdf.

Ajzen I. 2020. The theory of planned behavior: Frequently asked questions. Human Behavior and Emerging Technologies 2(4):314-324. https://doi.org/10.1002/hbe2.195

Al-Bukhari No. 590 (no date) Sahih Bukhari, Chapter: Loans, Payment of Loans, Freezing of Property andBankruptcy.https://ahadith.co.uk/permalinkhadith-5770.

Alam SS et al. 2012. Is religiosity an important factor in influencing the intention to undertake islamic home financing in Klang Valley?. World Applied Science Journal 19(7):1030-1041. https://doi. org/10.5829/idosi.wasj.2012.19.07.392

Bogoviz AV et al. 2019. Comparative analysis of formation of industry 4.0 in developed and developing countries. In Popkova EG, Ragulina $Y V$, Bogoviz AV. (eds) Industrial Revolution of the 21st Century, Studies in Systems, Decision and Control 169. Manhattan: Springer International Publishing. https://doi.org/10.1007/978-3-31994310-7_15

El-Menouar Y. 2014. The five dimensions of muslim religiosity: Results of an Empirical study. Method, Data, Analyses 8(1):53-78. doi: 10.12758/mda.2014.003

Fishbein M, Ajzen I. 1975. Attitude formation. Belief, Attitude, Intention, and Behavior, An Introduction to Theory and Research 216-287. https://doi. org/10.1016/B978-0-12-375000-6.00041-0

Fusilier M, Durlabhji S. 2005. Anexploration of student internet use in India the technology acceptance model and the theory of planned behaviour. Campus-Wide Information Systems 22(4):233-246. https://doi. org/10.1108/10650740510617539

Grande T. 2015. Identifying multivariate outliers with mahalanobis distance in SPSS. https://www. youtube.com $/$ watch? $\mathrm{v}=$ AXLAX6r5JgE.

Hair Jr JF et al. 2014. Multivariate Data Analysis. Ed. ke-7. Harlow: Pearson Education. www. pearsoned.co.uk.

Hansen T. 2008. Consumer values, the theory of planned behaviour, and online grocery shopping. International Journal of Consumer Studies 32(1983):128-137. https://doi.org/10.1111/ j.1470-6431.2007.00655.x

Hunt SD. 1991. Modern Marketing Theory: Critical Issues in The Philosophy of Marketing Science.
Shaffer TE, editor. Cincinnati: South-Western Publishing Co.

Huque SMR, Hafeez MH, Shariff MNM. 2014. The role of subjective norms in theory of planned behavior in the context of organic food consumption. British Food Journal 116(10):1561-1580. https://doi.org/ 10.1108/BFJ-05-2013-0105

Khalek AA, Ismail SHS. 2015. Why are we eating halal: Using the theory of planned behavior in predicting halal food consumption among generation Y in Malaysia. International Journal of Social Science and Humanity 5(7):608-612. dhttps://doi.org/10.7763/IJSSH.2015.V5.526

Lortie J, Castogiovanni G. 2015. The theory of planned behavior in entrepreneurship research: What we know and future directions. International Entrepreneurship and Management Journal 11:935-957.https://doi.org/10.1007/s11365015-0358-3

Mala IK, Pratikto H, Winarno A. 2020. Santripreneurship: Internalizing the values of independence in the digital era (Case of pondok pesantren in Malang Raya. Indonesian Journal of Business and Entrepreneurship 6(3):282-291. https://doi.org/10.17358/ijbe.6.3.282.

Nawawi No. 2 (no date) An-Nawawi's 40 hadith the forty hadith. https://ahadith.co.uk/nawawis40hadith. php.

Pavlou, Fygenson. 2006. Understanding and predicting electronic commerce adoption: an extension of the theory of planned behavior. MIS Quarterly 30(1):115. https://doi.org/10.2307/25148720

Shakona MY. 2013. The influence of religiosity on the intention of united states muslim tourists to choose a shariah compliant hotel [thesis]. South Carolina: Graduate School of Clemson University. http://search.proquest.com.ezaccess. library.uitm.edu.my/docview/1499232994?acco untid $=42518$.

Souiden N, Rani M. 2015. Consumer attitudes and purchase intentions toward Islamic banks: the influence of religiosity. International Journal of Bank Marketing 33(2):143-161. https://doi. org/10.1108/IJBM-10-2013-0115

Wibowo B. 2019. Spirituality, entrepreneurship education and entrepreneurial intention among moslem undergraduate students: spiritual wellbeing scaling application. Indonesian Journal of Business and Entrepreneurship 5(2):118-128. https://doi.org/10.17358/ijbe.5.2.118

Wibowo HA. 2017. The Effects of Indonesia Female 
Religiosity on Hijab - Wearing Behavior: An Extended of Theory of Reasoned Action. International Review of Management and Business Research 6(3):1040-1050. https://doi. org/10.17605/osf.io/r4gjc

Wibowo HA, Indarti N. 2020. Blue-Collar Workers Entrepreneurial Intentions and The Extended Theory of Reasoned Action: Incorporating SEM and Person-Item Map Analysis. Journal of Indonesian Economy and Business 35(3): 204235. https://doi.org/10.22146/jieb.52046

Wibowo HA, Masitoh MR. 2018. Measuring religiosity and its effects on attitude and intention to wear a hijab: Revalidating the scale. In Badri Munir Sukoco et al. (eds) Increasing
Management Relevance and Competitiveness. Ed. ke-1. London: CRC Press. https://doi. org/10.1201/9781351241892-44

Wijanto SH. 2008. Structural Equation Modeling Dengan Lisrel 8.8 Konsep \& Tutorial. Ed. ke-1. Yogyakarta: Graha Ilmu.

Yadav R, Pathak GS. 2017. Determinants of consumers: Green purchase behavior in a developing nation: Applying and extending the theory of planned behavior. Ecological Economics 134:114-122. https://doi.org/10.1016/j.ecolecon.2016.12.019

Yoon C. 2011. Theory of planned behavior and ethics theory in digital piracy: An integrated model. Journal of Business Ethics 100(3):405-417. https://doi.org/10.1007/s10551-010-0687-7 